\title{
Parental Aspirations and Its Influence on Career Choice Among Public Secondary School Students in Meru County, Kenya
}

\author{
Sarah Wambeti Njogu* Dr. Tarsilla Kibaara Dr. Paul Gichohi \\ Kenya Methodist University (KeMU), P. O Box 267-60200, Meru, Kenya
}

\begin{abstract}
Parents get involved in the education of their children through various ways; for example, in school activities, providing instructions on academic skills, engaging in and out of school learning activities, schooling process, providing learning resources and relevant learning experiences. Career choice by students is critical but a complicated task that involves a difficult process of decision making hence, parental involvement is necessary in creating awareness on possible career paths of their children. The study therefore, sought to assess the influence of parental aspirations on career choice among students in public secondary school in Meru County. Descriptive survey design was used. Through stratified, systemic and purposive sampling, 460 participants comprising 377 Form Four students, 36 principals, 36 career guidance teachers and 11 form four parents' representatives were selected from 364 schools. Overall response rate was $92.1 \%$. Data was collected using a questionnaire and an interview schedule. Analysis was done with the help of SPSS (Version 24) and Microsoft Excel. Mean and standard deviation were computed while linear regression analysis was used to examine the relationship between parental aspirations and career choice. The findings highlighted the critical role of parents in the selection process of careers of their children in public secondary. It was clear that the education level of parents is critical in informing career choices of children. The results show moderate influence of parental aspirations on careers selected by public secondary school students in Meru County where composite mean score is 3.35. Parents should strengthen their role in the provision of moral support, discussing and monitoring academic progress of children at school and at home; and rewarding them when they perform well in school, and should encourage their children to seek information on careers and exposing them to different career options.
\end{abstract}

Keywords: Career choice, parental aspirations, parental influence, parental involvement.

DOI: $10.7176 / \mathrm{JEP} / 10-22-10$

Publication date: August $31^{\text {st }} 2019$

\section{Introduction}

Sullivan and Baruch (2009) define career as an individual's work-related and other relevant experiences, both inside and outside an organization that form an individual's lifespan. According to Pam (2013), career choice is the act of deciding what one wants to do in life that determines ones success in the next stages of life. Scholars suggest that there is a link between children's career choice and parental aspirations and as such if parents are involved in supporting and assisting the adolescents in their career aspirations, then they are more likely to pursue their dream careers (Bates, 2015, Watson, Vernon, Seddon, Andrews \& Wang, 2016; Zhang, 2016; Wachira, 2018; KUCCPS, 2019). From the context of this study, parental aspiration refers to the extent to which the parents or family members influence the career decision paths of their children (Salami \& Salami, 2013). Bates (2015) opines that recognizing and understanding family influence on career choice may be more important now than in the past due to the changing composition, structure and dynamics of families. Consequently, the influence of parents on career choices among secondary school students cannot be underestimated.

Parental aspirations have been noted to comprise parental expectations, career related parental support and educational plans that parents have on their children (Zhang, 2016; Rinat, Cinamon \& Tova, 2015). In order to harness the full benefit of parental expectations, parents require some level of control and monitoring in the education of their children (Zhang, 2016).

Different countries have used different approaches to tap the benefits of parental influence on students' academic and career success. In Singapore, for example, the education curriculum has included parental involvement in career guidance where the parents are first educated and trained to ensure that they are able to guide their children through the education and career decision making process (Ministry of Education [Singapore], 2012). Similarly, in Nigeria, Eziuzo and Enueme (2013) noted that the formation of Parent Teacher Associations (PTA) was to heighten the combined involvement of teachers and parents in their children's education by assuming a partnership responsibility. In Kenya, the Ministry of Education (MoE) directed for the formation of the Parents Association (PA) with a view to encouraging a healthy working relationship between parents and teachers through assisting school management in monitoring, guiding, counseling and disciplining students among other functions (MoE, 2013). However, a study by Wachira (2018) noted that there has been limited effort to involve parents on career choice process of their children by secondary schools, yet the parents are actively involved in other school activities such as development projects.

Although previous studies have documented a link between parental aspirations and children career options 
(Wachira, 2018; Eziuzo and Enueme, 2013; KUCCPS, 2019; Zhang, 2016; Slovacek, Jacob \& Flenoury, 2015) few studies have examined magnitude and the extent to which parental aspirations influence career choice. This study aimed to examine the influence of parental aspirations on the choice of careers among students in public secondary school in Meru County with a view to strengthening the role of parents in this noble process. It hypothesized that parental aspirations do not significantly influence choice of career among students in public secondary schools in Meru County, Kenya. The investigation was guided by the following specific objectives:

- Find out what formed basis of preferring particular career paths of their children.

- Analyze how availability of finances in the family influence career paths of students

- Analyze how the education level of parents contribute to their ability to guide their children in career choice among public secondary students in Meru County

- Examine whether parental aspirations was statistically significant in influencing career choice among public secondary school students in Meru County.

\section{Literature Review}

Parental aspirations are manifested through parents' involvement in their children's life. Parental involvement in school education is conceptualized as the act of the parents being engaged with children in school activities, providing instructions of academic skills, engaging in and out of school learning activities, being involved in schooling process, provision of the required learning resources, providing educational experiences and providing relevant learning experiences (Zhang, 2016; Slovacek, Jacob \& Flenoury, 2015).

Hadjar and Aeschlimann (2015) contends that there is a strong link between occupational and workforce participation of the parents to vocational aspirations and career choice of their children. Scholars such as, Kaneez and Medha (2018); Mutekwe, Modiba and Mophosa (2011); Slovacek, Jacob and Flenoury (2015) have noted that one of the most influencing factors of career choice is social context of family and community. In particular, family financial and education background greatly influence students on what career they chose in a specific period of their life (Wachira, 2018; Kazi, Sharif \& Ahmad, 2017). In light of the above supposition Tejedor, Mangas and Sierra (2016) noted that students had difficulties in career decision making with those at risk of poverty and social exclusion being highly affected.

Studies conducted in Kenya by Oyamo and Amoth (2008), Wachira (2018) and Kingi (2013) revealed that a significant number of students tend to seek help from parents on career matters. However, parents with limited exposure to knowledge and little experience in higher education may be of little help to their children on career matters (Watson, Vernon, Seddon, Andrews \& Wang, 2016). Mbagwu and Ajaegbu (2016) contents that children of parents with high educational background were less likely to have difficulties in making career choices compared with those whose parents had low education background.

In order to guide the students appropriately, parents are expected to have relevant knowledge and skills. However, a study by Kingi, (2013) on the role of PTA in management of public secondary schools in Gatundu North, Kenya revealed that lack of training, lack of clear guidelines, lack of appropriate induction programs and lack of confidence were some of the challenges parents encountered while carrying out their mandate.

The reviewed studies show that parental involvement, control and monitoring as well as parental approval of desired courses were important aspects of parental aspirations that influenced career choice. However, studies were inconclusive on the extent to which parental career guiding role had been implemented in public secondary schools. These raises a pertinent issue on whether appropriate induction and training programs were in place and whether clear guidance policies were available to enable the parents make participate in decisions on career choices of their children. Based on this gap, this study was set out to examine the influence of parental aspirations on career choice among students in public secondary schools in Meru County.

\section{Research Methodology}

This study was conducted in public secondary schools in Meru County. It adopted descriptive survey research design. Questionnaires and structured interview schedules were used to collect data from form four students, career guidance teachers and principals and parents respectively. Stratified random sampling was used naturally existing sub- counties (strata) in Meru County. Public secondary schools were categorized into sub-strata; girls boarding, boys boarding, mixed boarding and mixed day secondary schools. In total, 36 secondary schools were sampled and equal number of principals and career guidance teachers. Systemic sampling was used to sample 377 form four students while 11 parents were sampled using purposive sampling technique, resulting to 460 respondents. Through pre-testing, questionnaires were tested for content and construct validity while reliability was computed where Cronbach's Alpha value (correlation coefficient, $\mathrm{r}=0.760$ ) was noted. Data was then analyzed using Statistical Package for Social Sciences (SPSS) version 24 and Microsoft Excel where, descriptive statistics (mean and standard deviation) and inferential statistic; linear regression analysis was computed accordingly. 


\section{Results and Discussions}

The overall response rate in this study was $92.1 \%$.

4.1 Incidences and ways on how parents can influence the selection of certain careers of their daughters and sons in public secondary schools in Meru County

A list of statements focusing on various incidences and ways on how parents can influence the selection of certain careers of their daughters and sons in public secondary schools was provided to students requiring them to rate the level of their agreement with the various statements which were presented in a 5-level Likert rating scale (Strongly agree - 5; Agree - 4; Neutral - 3; Disagree - 2; Strongly Disagree - 1). Results are summarized in Table 1.

Table 1. Incidences and ways on how parents can influence the selection of certain careers of their daughters and sons in public secondary schools in Meru County

\begin{tabular}{|c|c|c|c|c|c|c|c|}
\hline $\begin{array}{l}\text { Statements } \\
(\mathrm{N}=\mathbf{3 4 8})\end{array}$ & $\begin{array}{l}\text { Strongly } \\
\text { Disagree }\end{array}$ & Disagree & Neutral & Agree & $\begin{array}{l}\text { Strongly } \\
\text { Agree }\end{array}$ & Mean & SD \\
\hline $\begin{array}{l}\text { I perform well because } \\
\text { my parents give me } \\
\text { moral support }\end{array}$ & $6(1.7 \%)$ & $7(2.0 \%)$ & $20(5.7 \%)$ & $120(34.5 \%)$ & $195(56.0 \%)$ & 4.41 & .829 \\
\hline $\begin{array}{l}\text { The school } \\
\text { management invite } \\
\text { parents to discuss } \\
\text { academic progress of } \\
\text { students }\end{array}$ & $16(4.6 \%)$ & $18(5.2 \%)$ & $40(11.5 \%)$ & $131(37.6 \%)$ & $143(41.1 \%)$ & 4.05 & 1.071 \\
\hline $\begin{array}{l}\text { My parents encourage } \\
\text { me to seek information } \\
\text { about career }\end{array}$ & $14(4.0 \%)$ & $25(7.2 \%)$ & $36(10.3 \%)$ & $145(41.7 \%)$ & $128(36.8 \%)$ & 4.00 & 1.060 \\
\hline $\begin{array}{l}\text { Am rewarded by my } \\
\text { parents when I perform } \\
\text { well in school }\end{array}$ & $17(4.9 \%)$ & $25(7.2 \%)$ & $57(16.4 \%)$ & $123(35.3 \%)$ & $126(36.2 \%)$ & 3.91 & 1.117 \\
\hline $\begin{array}{l}\text { I discuss my end term } \\
\text { results with my mother }\end{array}$ & $23(6.6 \%)$ & $30(8.6 \%)$ & $54(15.5 \%)$ & $118(33.9 \%)$ & $123(35.3 \%)$ & 3.83 & 1.193 \\
\hline $\begin{array}{l}\text { I discuss my end term } \\
\text { results with both } \\
\text { parents }\end{array}$ & $30(8.6 \%)$ & $31(8.9 \%)$ & $66(19.0 \%)$ & $93(26.7 \%)$ & $128(36.8 \%)$ & 3.74 & 1.276 \\
\hline $\begin{array}{l}\text { I perform well because } \\
\text { my parents monitor my } \\
\text { academic progress }\end{array}$ & $27(7.8 \%)$ & $42(12.1 \%)$ & $59(17.0 \%)$ & $112(32.2 \%)$ & $108(31.0 \%)$ & 3.67 & 1.247 \\
\hline $\begin{array}{l}\text { I discuss my end term } \\
\text { results with my father }\end{array}$ & $34(9.8 \%)$ & $32(9.2 \%)$ & $62(17.8 \%)$ & $120(34.5 \%)$ & $100(28.7 \%)$ & 3.63 & 1.258 \\
\hline $\begin{array}{l}\text { My parents provide a } \\
\text { lot of information on } \\
\text { various careers that has } \\
\text { enabled me make a } \\
\text { choice }\end{array}$ & $51(14.7 \%)$ & $58(16.7 \%)$ & $56(16.1 \%)$ & $102(29.3 \%)$ & $81(23.3 \%)$ & 3.30 & 1.376 \\
\hline $\begin{array}{l}\text { Am punished by my } \\
\text { parents when I perform } \\
\text { poorly in class }\end{array}$ & $113(32.5 \%)$ & $89(25.6 \%)$ & $70(20.1 \%)$ & $56(16.1 \%)$ & $20(5.7 \%)$ & 2.37 & 1.247 \\
\hline $\begin{array}{l}\text { I feel pressured to } \\
\text { perform because my } \\
\text { parents have chosen a } \\
\text { career for me }\end{array}$ & $191(54.9 \%)$ & $98(28.2 \%)$ & $33(9.5 \%)$ & $16(4.6 \%)$ & $10(2.9 \%)$ & 1.72 & 1.006 \\
\hline $\begin{array}{l}\text { I choose a career like } \\
\text { that of my parents }\end{array}$ & $220(63.2 \%)$ & $77(22.1 \%)$ & $27(7.8 \%)$ & $16(4.6 \%)$ & $8(2.3 \%)$ & 1.61 & .974 \\
\hline Aggregate mean score & & & & & & 3.35 & \\
\hline
\end{tabular}

The results show a substantial influence of parental aspirations on careers selected by public secondary school students in Meru County where aggregate mean score is 3.35. This represents 67\% overall agreement level on influence of parental aspirations on career choice. It is noted that most parents provide moral support which ignites good performance (mean $=4.41$ ); are invited by school management to discuss academic progress of students $($ mean $=4.05)$; encourage their children to seek information on careers $($ mean $=4.00)$, and also reward them, when they perform well in school (mean $=3.91)$. It was also clear that many students do not choose careers like that of their parents (mean $=3.91$ ), and that choosing a career for a child does not necessary put pressure on a student to 
perform $($ mean $=1.61)$. The influence of parental aspirations in career choice among secondary school students was confirmed by majority of parents. To some parents, the influence starts early where parents get deeply involved in following up child's performance in schools. One parent ( $\left.\mathrm{SCDGB}_{1}\right)$ said, "I discuss the performance of my child in each subject with individual teacher during academic clinic days; that way, I am able to influence and encourage pursuance of some subjects".

During the interview, parents were asked to describe how they influenced the career path of their children. One parent $\left(\mathrm{SCIGB}_{2}\right)$ narrated how she spotted outstanding public speaking ability in her child and hence started building and growing the identified talent. Similarly, another parent (SCIGB 1 ) said that she noticed that her daughter was good in languages and hence the parent convinced the child to take journalism course; the parent further said, "I bought lot of books for my child to read and also looked for opportunities for her to make speeches in various gatherings in order to build confidence". Other responses regarding how parents were involved in influencing careers of their children were summarized as follows:

- Giving advice on why some careers are better than others.

- Allowing the child to choose the career that is going to help in securing a good paying job

- Provided information on the opportunities (jobs) available in given careers

- Guided children based on their strong subjects in high school

- Discussed with the child and provided advice according to performance in the subjects

- $\quad$ Showing and connecting children with mentors.

From the results, it emerged that parental aspirations play a key role in influencing career choice among public secondary school students. This is manifested through the provision of moral support, discussing and monitoring academic progress of students at school and at home; encouraging children to seek information on careers, and rewarding students when they perform well in school. These findings correlate with Kisuli, Kimani and Kombo (2012) who observed that $75.8 \%$ of the girls' respondents affirmed that their occupational choices were influenced by their mothers. A study by Mwaa (2016) conducted in Nairobi County also reported that $74.4 \%$ of the respondents agreed that their parents had provided the relevant educational opportunities, encouragement and resources for their educational development while $37.3 \%$ were certain that their parents were able to finance their vocational aspirations regardless of career chosen. However, 68.7\% agreed that the parents encouraged them to consider many different educational and career options.

\subsection{How availability of finances in the family influence career paths of students}

The social-economic status was reported by majority of the parents as having substantial influence on some students. This was evidenced by comments received from parents during interview session on the question that sought their opinion on whether the availability of finances in the family influences career paths of their children. Parents' responses were summarized as follows:

- Availability of financial resources makes it possible for parents to pay for whatever career a child wants / is interested in despite its cost.

- With stable finances, a family can focus and fund career path of a child rather than allowing her /him to take any career that comes on the way.

- In many cases, a child may be having the potential to take up certain course; for example medicine course, but family finances inability deter him/her to do it, hence, one end up taking up a course that favors the family's financial ability.

- The availability of finances influences the career paths because some careers are too costly hence poor family may not afford.

4.3 Parent's level of education and its impacts on career choice among public secondary schools in Meru County Many parents described parent's level of education as critical in providing informed guidance to the child. A parent $\left(\mathrm{SCKBB}_{1}\right)$ said, "When the parents are educated, they can tell the requirements for students to pursue certain careers and intentionally encourage them to work on those areas". It was also clear that educated parents are able to notice talents in their children in early stages in life, and hence use their knowledge and exposure to help them make better career choices. These results are similar to those of Hadjar and Aeschlimann (2015) who contends that there is a strong link between occupational and workforce participation of the parents to vocational aspirations and career choice of their children. Mbagwu and Ajaegbu (2016) affirms the above observation that, children from parents with high education background were not likely to have difficulties in making career choice as compared to those whose parents who have low education background.

\section{The extent to which parental aspirations influence career choice among public secondary school students in Meru County}

In Kenya, the subjects selected by students while at form three largely dictates the kinds of careers that one can 
pursue at institutions of higher learning upon completing secondary education. Consequently, students were asked to indicate their level of agreement on whether their parents influenced the selection of subjects which they were pursuing. Majority of form four students, $(244,70.1 \%)$, with a mean aggregate score of 3.50, agreed with the various assertions that aimed to investigate how students make career choice. In ascertaining the extent of the influence that parental aspiration had on career choice, a linear regression analysis was conducted where dependent variable (career choice) was regressed on the independent variable (parental aspirations). This helped to determine the prediction value of parental aspirations on career choice by students. The results are presented in three Tables; 2,3 and 4 .

Table 2 Influence of parental aspirations on career choice: ANOVA Results

\begin{tabular}{lllllll}
\hline Model & & Sum of Squares & df & Mean Square & F & Sig. \\
\hline \multirow{2}{*}{ X1 } & Regression & .654 & 1 & .654 & 5.477 & $.020^{\text {b }}$ \\
& Residual & 41.295 & 346 & .119 & &
\end{tabular}

a. Dependent Variable: Y

b. Predictors: (Constant), X1

Table 3 Influence of parental aspirations on career choice: Model Summary

\begin{tabular}{|c|c|c|c|c|}
\hline Model & $\mathrm{R}$ & R Square & Adjusted R Square & $\begin{array}{l}\text { Std. Error of the } \\
\text { Estimate }\end{array}$ \\
\hline$\overline{X 1}$ & $.125^{\mathrm{a}}$ & .016 & .013 & .34547 \\
\hline
\end{tabular}

a. Predictors: (Constant), X1

b. Dependent Variable: Y

Table 4 Influence of parental aspirations on career choice: Regression Weights

\begin{tabular}{|c|c|c|c|c|c|c|c|c|}
\hline \multirow[t]{2}{*}{ Model } & & \multicolumn{2}{|c|}{ Unstandardized Coefficients } & \multirow{2}{*}{$\begin{array}{l}\text { Standardized } \\
\text { Coefficients } \\
\text { Beta }\end{array}$} & \multirow[t]{2}{*}{$\mathrm{t}$} & \multirow{2}{*}{ Sig. } & \multicolumn{2}{|c|}{ Collinearity Statistics } \\
\hline & & $\mathrm{B}$ & Std. Error & & & & Tolerance & VIF \\
\hline & (Constant) & 3.241 & .115 & & 28.226 & .000 & & \\
\hline & $\mathrm{X} 2$ & .079 & .034 & .125 & 2.340 & .020 & 1.000 & 1.000 \\
\hline
\end{tabular}

a. Dependent Variable: $\mathrm{Y}$

The null hypothesis $(\mathrm{HO})$ predicted that parental aspirations do not significantly influence choice of career among students of public secondary schools in Meru County. Results in Table 2 shows $\mathrm{r}=.125^{*}$ while ANOVA Table 3 shows $P=.020$ which is less than the alpha value of $0.05 ; \mathrm{F}(1,346)=5.477$, hence we reject the null hypothesis and conclude that there is a positive and significant relationship between parental aspirations and the career choice of students of public secondary schools in Meru County. The results in Table 3 shows a prediction value of parental aspirations where $\mathrm{R}^{2}=.016$. This implies that parental aspirations explains/account for $16 \%$ of influence on career choice among public secondary school students in Meru County. The regression weights in Table 4 further confirm this finding where it shows that the influence of parental aspirations on career choice among public secondary school students will always exist at significant minimum $(\beta 2=.079, P=.020)$. This finding corroborates with Ehigbor and Akinlosotu (2016) who observed that there was a direct significant relationship $(\mathrm{r}=0.947 ; \mathrm{p}<0.01)$ between parents occupation and students career in public secondary schools in Ekpoma Metropolis, Nigeria. Similar findings were obtained from a study by Watson, Vernon, Seddon, Andrews and Wang (2016) in secondary schools in Australia who concluded that discussions with parents about university attendance strongly and positively correlated $(p=.059)$ with students desire for university education. Similarly, a study by Kisilu, Kimani and Kombo (2012) concluded that the major factor influencing secondary school girls' occupational aspirations can be traced to their family settings, parenting, siblings and other relatives.

\section{Conclusion}

The study concluded that there is a positive and significant relationship between parental aspirations and the career choice of students of public secondary schools in Meru County. It was also noted that the education level of parents was playing a critical role in informing career choices of children. The influence of parental aspirations in career choice among secondary school students was confirmed by majority of parents and as such, they ought to deliberately communicate their expectations to their children without being overly persuasive. The findings have implications on training of parents on their role in career selection as well as need for policies that outline unambiguously how secondary schools should involve parents in determining subjects that are taught and the choices made by their children. 


\section{Recommendations}

Parents play a key role in career selection process of their children. They provide moral support, discuss, monitor and reward academic progress; encourage children to seek information on careers, and provide learning resources, as well as sharing relevant learning experiences with their children. Ministry of Education should therefore harness parents 'aspirations by educating them on career choice so that they can stir secondary school students to choices that align with the areas of interest, talents and abilities. The principals of secondary schools should arrange to sensitize parents during Parent Associations (PA) meetings, and also come up with policies and mechanisms for involving parents on matters of career choice of students. The study also recommend the need for school BOM to foster a concerted effort and corroborations with parents, teachers and students in ensuring an informed career choice among secondary school students.

\section{References}

Bates, C.W. (2015).The Influence of Family on the Career Interests and Choices of Youth. International Journal of Education and Social Science, 2 (9) 67-73. Retrieved from www.ijessnet.com

Ehigbor, B.O \& Akinlosotu,T.N.(2016).Parents Occupation as Correlate of Students Career Aspiration in Public Secondary Schools in Ekpoma Metropolis. Edo State, Nigeria. International Journal of Arts And Humanities, 5(3), 197-213. Retrieved from https://www.ajol.info $>$ article $>$ view

Eziuzo,G. O., \& Enueme, C.P.( 2013).Contribution of PTA to Secondary School Management in Nigeria; Principals'Perspection. Journal of Emerging Trends in Education Research and Policy Study (JETERAPS)4(6)835-841. Retrieved from https://www.questia.com>journal

Hadjar, A., \& Aeschlimann, B. (2015) Gender stereotypes and gendered vocational aspirations among Swiss secondary school students. Journal of Educational Research, 57(1), 22-42. Retrieved from doi: $10.1080 / 00131881.2014 .983719$

Kaneez, B.-S., \& Medha, K. (2018). Factors Influencing Grade 10 Students' Career Choice in Mauritius. International Journal of Academic Research in Progressive Education and Development, 7(2), $30-44$. Retrieved from http://dx.doi.org/10.6007/IJARPED/v7-i2/4081 doi: 10.6007/IJARPED/v7- i2/4081

Kazi, A. A., Sharif, N. \&Ahmad, N. (2017). Factors Influencing Career Choices: Empirical Evidence from Business Students. Journal of South East Asian Research. 2017(2017)

Kingi, P. M. (2013). The Role of Parent Teachers Association in the Management of Public Secondary Schools: Gatundu North, Kenya. International Journal of Science and Research 4, (9), 2102-2107. Retrieved from https://www.reseaerchgate.net

Kisuli, J., Kimani, E., \& Kombo, D. (2012). Factors Influencing Occupational Aspirations among Girls in Secondary Schools in Nairobi Region, Kenya. Journal of Prime Research on Education, 2(4), $244-253$. Retrieved from https://ir-library.ku.ac.ke/handle/123456789/7741

KUCCPS. (2019). The Essential Career Guide: Making an Informed Choice. Kenya Literature Bureau. Kenya .

Mbagwu, M. I., \& Ajaegbu, O. O. (2016). Influence of parents educational background on career choice of teenagers among senior secondary schools in Owerri. Educational Journal of Psychology,2016(2)14-20. Retrieved from doi:10.5348/p13-2016-9-OA-3

Ministry of Education, (2012). Education and Career Guidance (ECG) Syllabus for Secondary: Student Development Curriculum Division. Singapore. Retrieved from https://www.moe.gov.sg $>$ syllabuses $>$ files2014-education-and-career-guidance-(secondary)- sylabus.pdf

Ministry of Education, (2013). The Basic Education Act, No-14 0f 2013. Retrieved from www.education.go.ke.

Mutekwe, E., Modiba, M., \& Maphosa, C. (2011).Factors affecting female students career choice and aspirations. A Zimbabwean Example. Journal of Social Science, 29(2), 133-141. Retrieved from https://doi.org/10.1080/09718923.2011.11892963

Mwaa, M. A.(2016). Parental Factors Influencing Career Choice among High School Students in Nairobi County (Post Graduate Degree) University of Nairobi. Retrieved from https://scholar,google.com/s

Oyamo, O. R., \& Amoth, D. (2008). Choice of Final Year Options by Undergraduates Students from Marketing 121 at Multimedia University (Masters' Thesis, Multimedia University). Retrieved from https://www.coursehero.com

Pam, M. N. (2013).Career Choice in Psychology Dictionary. Retrieved from https:psychologydictonary.org/career

Rinat, M., Cinamon, R. G \& Tova, M. (2015). What Shapes Adolescents' Future Perceptions? The Effects of Hearing Loss: Social Affiliations and Career Self Efficacy The Journal of Deaf Studies and Deaf Education, 20(4), 399-407. Retrieved from https://doi.org/10.1093/deaf/env023

Slovacek, S., Jacob, S.,\& Flenoury,L. (2015). Dynamic Influence of Family on College and Career Choices of Underrepresented Minorities in the Biomedical Sciences. Journal of Education and Human Development, 4 (4), 63- 76. Retrieved from doi: 10.15640/jehd.v4n4a9

Sullivan, S., \& Baruch, Y. (2009). Advances in career theory and research: A critical review and agenda for future exploration. Journal of Management, 36(6), 1542-1578. Retrieved from doi: 10.1177/0149206309350082 
Tejedor, M. E., Mangas, L. S., \& Sierra, B. J. (2016). Measuring the relationship between career guidance and adult training needs. Analysis and assessment of results from the perspective of the social responsibility. Univeritas Psychlogica,15(4).retrieved from https://dx.doi.org/10.1144/javeriana.upsy15- 4mrcg

Wachira, D. W. (2018). Relationship Between Parental Variables and Career Choices Among Students in Mixed Day Secondary Schools in Kinangop Sub-County Nyandarua County, Kenya (Master's Thesis, Kenyatta University). Retrieved from https:// ir-library.ku.ac.ke

Watson, S., Vernon, L., Seddon, S., Andrews,Y., \& Wang, A. (2016). Parents influencing secondary school students university aspirations: Multilevel approach using school- SES. Issues in Educational Research, 26(4), 673-693. Retrieved from www.iier.org.au

Zhang, L. (2013).Effects of college educational debt on graduate school attendance and early career and lifestyle choices. Journal of Education Economics, 21(2), 154-175. Retrieved from doi:10.1080/09645292.2010.545204 